\title{
Influence of Operational Parameters on Rapid Nitrate Removal Using an Electrochemical Flow Cell
}

\author{
A. K. M. Ashadullah and Naoyuki Kishimoto
}

\begin{abstract}
Nitrate contamination is a great concern all over the world. However, the conventional biological processes like the modified Ludzack-Ettinger process are time-consuming. Accordingly, a rapid process for nitrate removal is desired. We conceived an electrochemical process for rapid removal of nitrate, which contained electrochemical reduction of nitrate to ammonia and electrochemical break-point chlorination of ammonia. In this research, we investigated effects of operational parameters such as volumetric electric charge, flow rate and chloride ion concentration on electrochemical nitrate removal. A hand-made divided flow cell with a copper mesh cathode, a platinum-coated titanium anode and a cation exchange membrane as a separator was developed as well as applied to the treatment of synthetic water containing $1.42 \mathrm{mM}$ of nitrate at various volumetric electric charges, flow rates and chloride ion concentrations. As a result, it was observed that the flow cell operated at a flow rate of $20 \mathrm{~mL} / \mathrm{min}$, chloride ion concentration of $800 \mathrm{mg} / \mathrm{L}$, volumetric electric charge of $5,100 \mathrm{C} / \mathrm{L}$ and at $\mathrm{pH} 7$ successfully removed nitrate from $1.42 \mathrm{mM}$ to $0.43 \mathrm{mM}$ without ammonia and nitrite accumulation within 1 minute contact time. Consequently, the electrochemical technique was thought to be feasible for the rapid removal of nitrate from water streams.
\end{abstract}

Index Terms-Break-point chlorination, biological process, electrochemical process, nitrate contamination.

\section{INTRODUCTION}

\section{A. Electrochemical Water Treatment Concepts}

Literally, the electrochemical water treatment concept was first commenced in the beginning of nineteenth century in the United Kingdom (UK). After that, about a century has passed with the extensive researches by many scholars all around the world in the electrochemical field. On the other hand, the accessibility of electrical power has facilitated to enhance the electrochemical technologies to the door point of many fields [1]. Nowadays, these techniques are frequently employed elsewhere to deal with the water treatment for several nitrogenous compounds removal, including nitrate $\left(\mathrm{NO}_{3}{ }^{-}\right)$, nitrite $\left(\mathrm{NO}_{2}{ }^{-}\right)$and ammonia $\left(\mathrm{NH}_{3}\right)$ [2]. However, the World Health Organization (WHO), United States Environmental Protection Agency (USEPA), and European Community (EC) set the maximum contaminant level (MCL) in drinking water to be $50 \mathrm{mg} \mathrm{NO}{ }_{3}^{-} / \mathrm{L}, 0.5 \mathrm{mg} \mathrm{NO}_{2}^{-} / \mathrm{L}$ and $0.5 \mathrm{mg} \mathrm{NH}_{4}^{+} / \mathrm{L}$.

Manuscript received May 10, 2015; revised September 11, 2015.

A. K. M. Ashadullah is with the Department of Environmental Solution Technology, Graduate School of Science and Technology, Ryukoku University, 1-5 Yokotani, Seta Oe-cho, Otsu, Shiga 520-2194, Japan (e-mail akmashadullah@gmail.com).

N. Kishimoto is with the Department of Environmental Solution Technology, Faculty of Science and Technology, Ryukoku University, 1-5 Yokotani, Seta Oe-cho, Otsu, Shiga 520-2194, Japan (e-mail: naoyuki@rins.ryukoku.ac.jp).
Besides, different discharge standards were demarcated based on the receiving environment such as in the fresh water body 50-100 $\mathrm{mg} \mathrm{NO}_{3}^{-} / \mathrm{L}$, sea water $200 \mathrm{mg} \mathrm{NO}_{3}^{-} / \mathrm{L}$ and in the sensitive areas $50-75 \mathrm{mg} \mathrm{NO}_{3}{ }^{-} / \mathrm{L}$ [3]. Due to elimination of nitrogenous compounds from different sources of water, many researchers have focused on the electrochemical reduction of $\mathrm{NO}_{3}{ }^{-}$, because it shows comparatively high treatment efficiency, negligible amount of sludge production, small area consumption and overall, relatively low investment costs [4]. In the last decades, numerous cathode materials were studied by several researchers in the electrochemical denitrification such as, $\mathrm{Cu}, \mathrm{Fe}, \mathrm{Zn}, \mathrm{Pt} / \mathrm{Ir}, \mathrm{Pd}$ and $\mathrm{Au}$ [5]. Some electrodes like $\mathrm{Cu}$ and $\mathrm{Fe}$ presented quite efficient promoters for $\mathrm{NO}_{3}{ }^{-}$reduction [6].

\section{B. $\mathrm{NO}_{3}{ }^{-}$Conversion Mechanism in an Electrochemical Flow Cell}

In an electrochemical cell the $\mathrm{NO}_{3}{ }^{-}$is mainly reduced to $\mathrm{NO}_{2}{ }^{-}$and $\mathrm{NH}_{3}$ in the course of cathodic cycle (reactions (1) and (2)), and the produced $\mathrm{NO}_{2}{ }^{-}$and $\mathrm{NH}_{3}$ are oxidized to $\mathrm{NO}_{3}{ }^{-}$ and nitrogen gas $\left(\mathrm{N}_{2}\right)$ in the anodic cycle (reactions (3) and (4)) [7].

Reactions in the cathodic cycle:

$$
\begin{gathered}
\mathrm{NO}_{3}{ }^{-}+\mathrm{H}_{2} \mathrm{O}+2 \mathrm{e}^{-} \rightarrow \mathrm{NO}_{2}^{-}+2 \mathrm{OH}^{-} \\
2 \mathrm{NO}_{3}^{-}+12 \mathrm{H}_{2} \mathrm{O}+16 \mathrm{e}^{-} \rightarrow 2 \mathrm{NH}_{3}+18 \mathrm{OH}^{-}
\end{gathered}
$$

Reactions in the anodic cycle:

$$
\begin{array}{r}
\mathrm{NO}_{2}^{-}+\mathrm{H}_{2} \mathrm{O} \rightarrow \mathrm{NO}_{3}^{-}+2 \mathrm{H}^{+}+2 \mathrm{e}^{-} \\
2 \mathrm{NH}_{3} \rightarrow \mathrm{N}_{2}+6 \mathrm{H}^{+}+6 \mathrm{e}^{-}
\end{array}
$$

However, during electrochemical reduction of $\mathrm{NO}_{3}^{-}$at a constant potential it has been demonstrated that the simultaneous electrochemical oxidation of $\mathrm{NH}_{3}$ to $\mathrm{N}_{2}$ seems to be difficult [8]. Therefore, it is challenging to find out the appropriate conditions to perform both cathodic reduction of $\mathrm{NO}_{3}{ }^{-}$and anodic oxidation of the produced $\mathrm{NH}_{3}$ [9].

\section{Nitrate Removal Using Electrochemically Produced $\mathrm{HOCl}$}

In general, in the course of electrolysis, water containing sufficient amount of chloride ion $\left(\mathrm{Cl}^{-}\right)$produces chlorine $\left(\mathrm{Cl}_{2}\right)$ by an anodic oxidation, which reacts with water $\left(\mathrm{H}_{2} \mathrm{O}\right)$ and forms hypochlorous acid ( $\mathrm{HOCl})$ as follows:

$$
\begin{gathered}
2 \mathrm{Cl}^{-} \rightarrow \mathrm{Cl}_{2}+2 \mathrm{e}^{-} \\
\mathrm{Cl}_{2}+\mathrm{H}_{2} \mathrm{O} \rightarrow \mathrm{HOCl}+\mathrm{HCl}
\end{gathered}
$$


The $\mathrm{HOCl}$ further reacts with $\mathrm{NH}_{3}$ and produces $\mathrm{N}_{2}$ [10]. It has been also reported that $\mathrm{Ti} / \mathrm{TiO}_{2}-\mathrm{RuO}_{2}$ anode can efficiently remove $\mathrm{NH}_{3}$ with the appropriate amount of $\mathrm{Cl}^{-}$ concentration in the electrolyte [11]. The $\mathrm{NO}_{3}{ }^{-}$removal from potable water and wastewater as well as the concentrated solutions that come from the reverse osmosis (RO), electro-dialysis (ED) and ion exchange (IE) resin is a critical issue in environmental technology. Copious research works have been done for the removal of $\mathrm{NO}_{3}{ }^{-}$which include biological, catalytic, and electro-catalytic methods [12].

The electrochemical reduction of $\mathrm{NO}_{3}{ }^{-}$leads to a relatively broad spectrum of products, such as $\mathrm{N}_{2}$, hydroxylamine $\left(\mathrm{NH}_{2} \mathrm{OH}\right)$, nitrous oxide $\left(\mathrm{N}_{2} \mathrm{O}\right)$, nitric oxide $(\mathrm{NO})$ and $\mathrm{NH}_{3}$ [13]. The pattern of $\mathrm{NO}_{3}^{-}$reduction on catalysts and electro-catalysts can be stated as follows [14]:

$$
\begin{gathered}
\mathrm{NO}_{(\mathrm{g})} \\
\mathrm{NO}_{3}{ }^{-} \rightarrow \mathrm{NO}_{2}-\rightarrow \\
\stackrel{\mathrm{NO}}{\downarrow} \rightarrow \mathrm{NH}_{2} \mathrm{OH} \rightarrow \mathrm{NH}_{3} \\
\mathrm{~N}_{2} \mathrm{O}_{(\mathrm{g})} \rightarrow \mathrm{N}_{2(\mathrm{~g})}
\end{gathered}
$$

Therefore, it is likely to find out the proper conditions to perform both cathodic reduction of $\mathrm{NO}_{3}{ }^{-}$to $\mathrm{NO}_{2}{ }^{-}$and $\mathrm{NH}_{3}$ and the anodic oxidation of the produced $\mathrm{NH}_{3}$ with the presence of $\mathrm{Cl}^{-}$.

\section{Research Objectives}

The aim of this research work was to demonstrate the $\mathrm{NO}_{3}{ }^{-}$ removal by inserting a cation exchange membrane between the two-compartment electrochemical flow cell to evaluate the $\mathrm{NO}_{3}^{-}$removal performances. Where, cation exchange membrane functioned as to block the flow of anions and water molecules to the anode compartment but supported only the cations to pass through the cathodic compartment. In this research, the influence of several parameters such as cathode materials, volumetric electric charges, flow rates, and $\mathrm{Cl}^{-}$ concentrations were investigated for the improvement of electrochemical denitrification process.

\section{MATERIALS AND METHODS}

\section{A. Cyclic Voltammetry}

The cyclic voltammetry (CV) was used to investigate $\mathrm{NO}_{3}$ reduction characteristics of copper cathode. Here, the saturated $\mathrm{Ag} / \mathrm{AgCl}$ electrode was used as a reference electrode and a platinum-coated titanium $(\mathrm{Ti} / \mathrm{Pt})$ electrode was used as a counter electrode. Working electrode was prepared by polishing the surface with an alumina-based abrasive (\#800 \#100, 3M, Japan). Test solution was prepared with reagent grade chemicals (Wako Chemical, Japan) of potassium sulphate $\left(\mathrm{K}_{2} \mathrm{SO}_{4}\right)$ and potassium nitrate $\left(\mathrm{KNO}_{3}\right)$ diluted with deionized water. The $\mathrm{K}_{2} \mathrm{SO}_{4}$ was used as a supporting electrolyte to ensure sufficient conductivity, since it is a strong electrolyte and fully ionized in water. The concentration of the supporting electrolyte was determined considering the similarity to general tap water conductivity. The $\mathrm{pH}$ and conductivity of $1 \mathrm{mM} \mathrm{K}_{2} \mathrm{SO}_{4}$ solution was 6.8 and $0.29 \mathrm{mS} / \mathrm{cm}$, respectively. On the other hand, the $\mathrm{pH}$ and conductivity of $1 \mathrm{mM} \mathrm{K}_{2} \mathrm{SO}_{4}$ with $1.42 \mathrm{mM} \mathrm{KNO}_{3}$ solution was 5.3 and $0.44 \mathrm{mS} / \mathrm{cm}$, respectively. The surface area of the working electrode was $1.0 \mathrm{~cm}^{2}$. The potential sweep was cycled five times between +0.15 to $-1.23 \mathrm{~V}$ at a scan rate of $50 \mathrm{mV} / \mathrm{sec}$ from forward to backward direction for getting stable polarization using an automatic polarization electrochemical system (HSV100, Hokuto Denko, Japan).

\section{B. Experimental Apparatus for Electrolysis}

Fig. 1 (a) shows the experimental setup and (b) shows the structure of the electrolytic flow cell. The laboratory scale experimental system was composed of a hand-made electrolytic flow cell, a feed pump (RP-1000, EYELA, Japan), and a DC power supply (PW18-3AD, Kenwood, Japan). The flow cell was divided into two compartments, namely cathodic and anodic by inserting a flat sheet cation exchange membrane (Nafion NE-1110, DuPont, USA) between two compartments. Ten sheets of copper meshes (\#40/36, 0.28 $\mathrm{mm}$ in the diameter of $\mathrm{Cu}$ wire) with the configuration of 50 $\mathrm{cm}^{2}$ constituted the cathode by stacking them in the cathodic chamber. The effective cathode area amounted to $2892 \mathrm{~cm}^{2}$. The anodic compartment was equipped with a Ti/Pt plate electrode at the outside of the compartment with the effective area of $50 \mathrm{~cm}^{2}$ and was filled with a fluorocarbon mesh sheet. The flame of the compartment was made of a silicon sheet with $4 \mathrm{~mm}$ in thickness for cathodic and $1 \mathrm{~mm}$ in thickness for anodic one. Accordingly, the empty volume of cathodic and anodic compartment was $20 \mathrm{~cm}^{3}$ and $5.0 \mathrm{~cm}^{3}$, respectively. All parts of the cell were fastened tightly with 8 bolts.

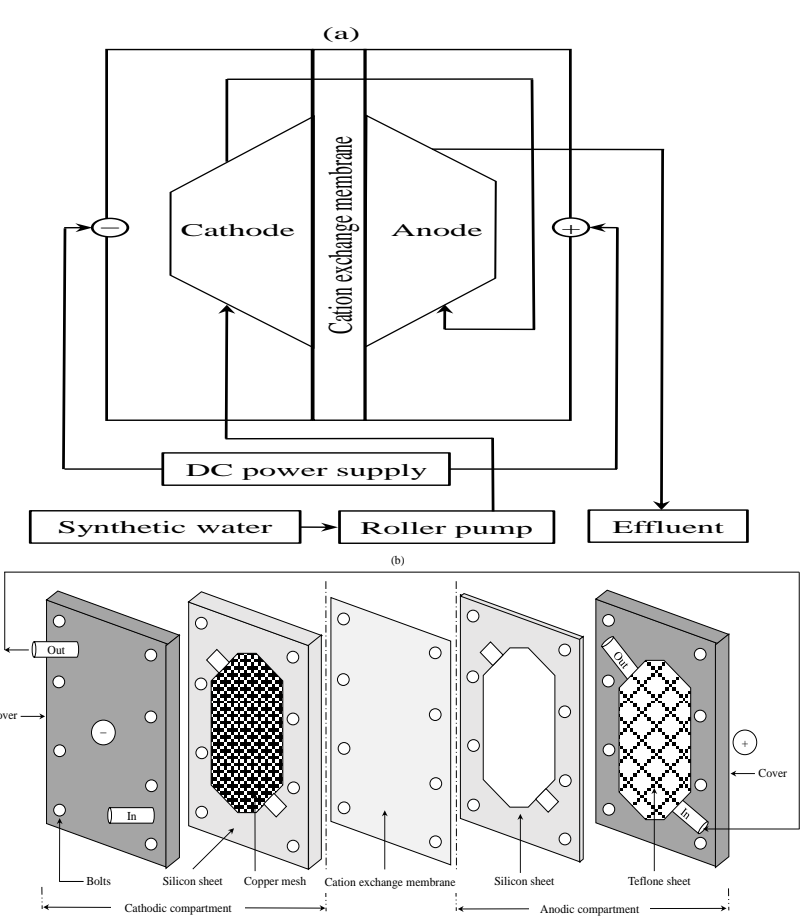

Fig. 1. (a) Experimental setup and (b) Structure of the electrolytic flow cell.

\section{Experimental Procedure for Electrochemical Denitrification}

Before each experimental run the positive and negative terminal of the DC power supply was perfectly connected with the anode and cathode, respectively. After that, the feed pump was switched on to feed the synthetic water into the electrolytic flow cell. Then the DC power supply was turned on for galvanostatic electrolysis. All the runs were performed 
under air-conditioned room temperature at $25^{\circ} \mathrm{C}$. For sampling and analysis the effluent from the anodic compartment was collected by using glass bottles. The synthetic water ingredients used for the experiments are given in the Table I. The synthetic water was fed into the cathodic compartment, and then its effluent flowed into the anodic compartment.

TABLE I: LIST OF CHEMICALS USED IN THE EXPERIMENT

\begin{tabular}{lll}
\hline Chemicals & \multicolumn{1}{c}{ Concentration } & \multicolumn{1}{c}{ Function } \\
\hline $\mathrm{K}_{2} \mathrm{SO}_{4}$ & $174.25 \mathrm{mg} / \mathrm{L}(1 \mathrm{mM})$ & Supporting electrolyte \\
$\mathrm{KNO}_{3}$ & $144.43 \mathrm{mg} / \mathrm{L}(1.42 \mathrm{mM})$ & Source of nitrate ion \\
$\mathrm{NaCl}$ & $329.68-1318.72 \mathrm{mg} / \mathrm{L}$ & Source of chloride ion \\
\hline
\end{tabular}

Before each experimental operation the copper meshes were submersed into $50 \mathrm{mM}$ citric acid monohydrate $\left(\mathrm{C}_{6} \mathrm{H}_{8} \mathrm{O}_{7} . \mathrm{H}_{2} \mathrm{O}\right)$ solution for 5 minutes for removing the oxide layers. Then, they were washed with deionized water for several times and used for the experiment.

\section{Analytical Procedure}

All the analyses were done according to the standard methods [15]. The $\mathrm{pH}$ and conductivity was measured by a $\mathrm{pH}$ meter (B-212, Horiba, Japan) and a conductivity meter (Twin cond, B-173, Horiba, Japan). The concentrations of $\mathrm{NO}_{3}{ }^{-}$and $\mathrm{NO}_{2}{ }^{-}$were determined by the ion chromatography (PIA-1000, Shimadzu, Japan) and $\mathrm{NH}_{4}{ }^{+}$was determined by the indophenol method. Total chlorine and free chlorine was measured by a chlorine meter (HI95711, Hanna Instruments, Romania). Deionized water of conductivity less than $1 \mu \mathrm{S} / \mathrm{cm}$ was used for the dilution and preparation of standard solution.

\section{RESULTS AND DISCUSSION}

\section{A. Cyclic Voltammetry Curve Analysis on Copper as Cathode Material}

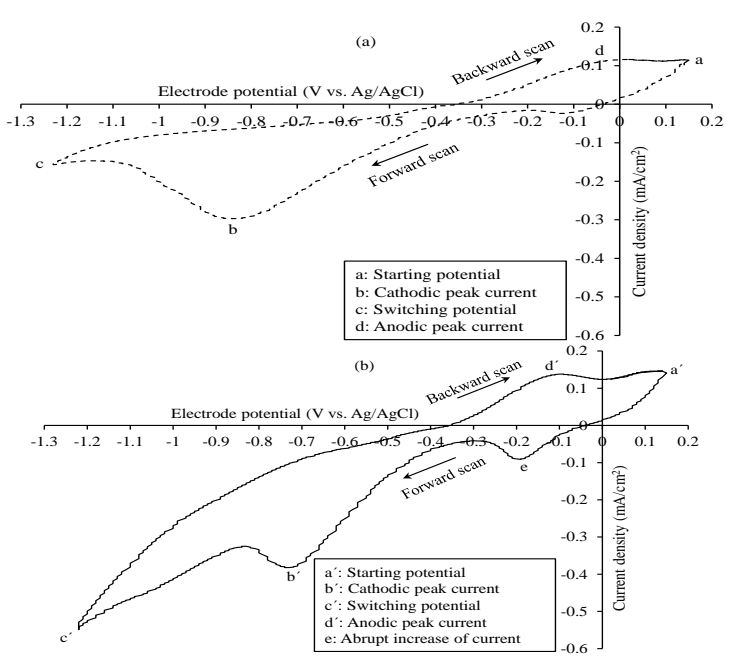

Fig. 2. Cyclic voltammograms of (a) $1 \mathrm{mM} \mathrm{K} 2 \mathrm{SO} 4$ and (b) $1 \mathrm{mM} \mathrm{K} 2 \mathrm{SO} 4$ with $1.42 \mathrm{mM} \mathrm{KNO} 3$ at the scan rate of $50 \mathrm{mV} / \mathrm{s}$ using a copper working electrode with a surface area of $1.0 \mathrm{~cm}^{2}$.

Fig. 2 (a) shows the cyclic voltammogram of $1 \mathrm{mM} \mathrm{K}_{2} \mathrm{SO}_{4}$ at the scan rate of $50 \mathrm{mV} / \mathrm{s}$ on copper as a working electrode. The CV curve was developed in combination of the capacitive or non-faradic and faradic current. The graph in Fig. 2 (a) shows the small amount of non-faradic current which was used for the accumulation or removal of electrical charges on the electrode and electrolyte solution near the electrode. Conversely, the faradic current higher than the non-faradic current was the result of electrochemical reactions at the electrode surface. The CV developed two peak currents at the forward and backward scan directions namely, cathodic (b) and anodic (d) peak current. On the other hand, Fig. 2 (b) shows the $\mathrm{CV}$ of $1 \mathrm{mM} \mathrm{K}_{2} \mathrm{SO}_{4}$ with $1.42 \mathrm{mM} \mathrm{KNO}_{3}$ under the same condition. This $\mathrm{CV}$ curve showed two cathodic peak currents at point $\mathrm{e}$ and $\mathrm{b}^{\prime}$. Accordingly, $\mathrm{NO}_{3}^{-}$was mainly reduced by the cathodic reduction at the negative potential of $-0.2 \mathrm{~V}$ at point e and the reduced species were thought to be stable intermediate byproducts such as $\mathrm{NO}_{2}^{-}$or $\mathrm{NH}_{3}$ [16].

Significantly, at the backward scan direction another recognizable anodic current except anodic peak current except a peak d' was not observed, which denotes that the reduced species of $\mathrm{NO}_{3}{ }^{-}$was not reoxidized to $\mathrm{NO}_{3}{ }^{-}$. Although, Fig. 2 (a) and (b) showed the similar CV curve pattern, Fig. 2 (b) showed higher electrolytic current than Fig. 2 (a) due to higher electrical conductivity of the used electrolytic solution. In the above discussions, only one additional reduction peak (e) was observed in Fig. 2 (b). This seems to indicate one step $\mathrm{NO}_{3}{ }^{-}$reduction mechanism such as $\mathrm{NO}_{3}{ }^{-}$into $\mathrm{NO}_{2}{ }^{-}$(reaction (1)), $\mathrm{NO}_{3}{ }^{-}$into $\mathrm{NH}_{3}{ }^{-}$(reaction (2)) or $\mathrm{NO}_{3}{ }^{-}$into $\mathrm{N}_{2}$ as follows [17]:

$$
2 \mathrm{NO}_{3}{ }^{-}+6 \mathrm{H}_{2} \mathrm{O}+10 \mathrm{e}^{-} \rightarrow \mathrm{N}_{2}+12 \mathrm{OH}^{-}
$$

\section{B. Influence of Volumetric Electric Charge and Flow Rate on Conversion of Nitrate to Nitrite and Ammonia}

A series of electro-reduction experiments was started in the synthetic solution with $1.42 \mathrm{mM}$ of $\mathrm{KNO}_{3}$ and $1 \mathrm{mM}$ of $\mathrm{K}_{2} \mathrm{SO}_{4}$ at the initial $\mathrm{pH}$ of about 5.5. Fig. 3 (a) shows the effect of volumetric electric charge on transformation of $\mathrm{NO}_{3}{ }^{-}$to $\mathrm{NO}_{2}^{-}$and $\mathrm{NH}_{3}$ at a constant flow rate of $20 \mathrm{~mL} / \mathrm{min}$, which was equivalent to the space velocity (SV) of $1.0 \mathrm{~min}^{-1}$. Here, total nitrogen (TN) indicates the sum of $\mathrm{NO}_{3}{ }^{-}, \mathrm{NO}_{2}{ }^{-}$and $\mathrm{NH}_{3}$ nitrogen concentration. The applied electrolytic current ranged from 0.10 to $2.90 \mathrm{~A}$, which was equivalent to the volumetric electric charge from 300 to $8,700 \mathrm{C} / \mathrm{L}$. At these volumetric electric charges the main reduced intermediate products were found to be $\mathrm{NO}_{2}^{-}$and $\mathrm{NH}_{3}$ [16]. The enhancement of $\mathrm{NO}_{3}{ }^{-}$reduction with the increase in volumetric electric charge was observed at 300, 1,500 and $2,700 \mathrm{C} / \mathrm{L}$ where $\mathrm{NO}_{3}{ }^{-}$concentration was measured $1.18,0.92$ and $0.71 \mathrm{mM}$, respectively. This result indicates that $17 \%$ of the initial $\mathrm{NO}_{3}{ }^{-}$was reduced at $300 \mathrm{C} / \mathrm{L}, 35 \%$ at $1,500 \mathrm{C} / \mathrm{L}$ and $50 \%$ at $2,700 \mathrm{C} / \mathrm{L}$.

An increase in the reduction rate of $\mathrm{NO}_{3}{ }^{-}$at the higher electrolytic current was reasonable, since the electrochemical reduction rate depends on the electrolytic current under the electron transfer-controlled condition. In fact this assumption was true for the volumetric electric charge of 300 to 2,700 $\mathrm{C} / \mathrm{L}$ and intensely supports that $\mathrm{NO}_{3}{ }^{-}$reduction increase with the increase in supplied electric charge within the specific range [18]. However, the $\mathrm{NO}_{3}{ }^{-}$reduction rate was unchanged from the volumetric electric charges of 2,700 to 8,700 C/L. In this case it can be supposed that excess electric charges applied were consumed for hydrogen evolution at the cathode and the hydrogen adsorbed on the cathode affected the $\mathrm{NO}_{3}$ 
reduction process [19], [20]. On the other hand, $\mathrm{NO}_{2}$ concentration remained a constant at the volumetric electric charge from $300 \mathrm{C} / \mathrm{L}$ to $2,700 \mathrm{C} / \mathrm{L}$, which was found to be $0.29 \mathrm{mM}$. In the higher electric charge range $\mathrm{NO}_{2}^{-}$ concentration gradually decreased with the increase in volumetric electric charges. It can be presumed that hydrogen evolution could play an important role in the cathodic reduction of $\mathrm{NO}_{3}{ }^{-}$. The hydrogen evolution hindered the transformation of $\mathrm{NO}_{3}^{-}$to $\mathrm{NO}_{2}^{-}$, though did not play any inhibition role in $\mathrm{NH}_{3}$ formation from $\mathrm{NO}_{3}{ }^{-}$[12].
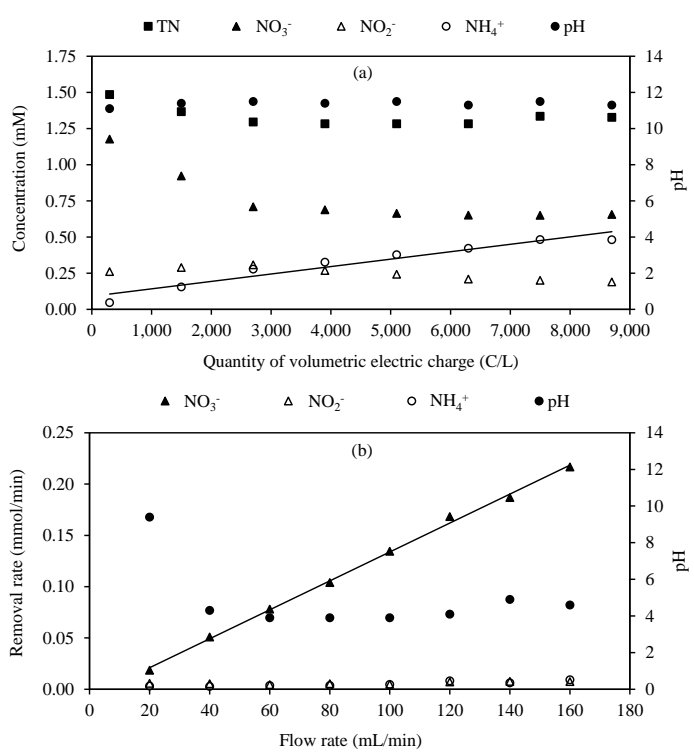

Fig. 3. Effects of (a) volumetric electric charge and (b) flow rate on transformation of $\mathrm{NO}_{3}{ }^{-}$to $\mathrm{NO}_{2}{ }^{-}$and $\mathrm{NH}_{3}$. The flow rate was set at $20 \mathrm{~mL} / \mathrm{min}$ (SV: $1.0 \mathrm{~min}^{-1}$ ) for Fig. 3 (a) and the volumetric electric charge was fixed at 1,500 C/L for Fig. 3 (b).

A clear linear relationship between $\mathrm{NH}_{3}$ formation and the volumetric electric charge was observed $\left(R^{2}=0.934\right)$ in Fig. 3 (a) which supports the above discussion. The pHs of all treated solutions increased from about 5.5 to about 11.5. This was happened mainly due to the reactions forming hydroxide ions $\left(\mathrm{OH}^{-}\right)$during the electrochemical reduction of $\mathrm{NO}_{3}^{-}$ (equations (1) and (2)). The high $\mathrm{pH}$ along with almost constant TN concentration of electrolyzed effluent water recommends that $\mathrm{NO}_{3}{ }^{-}$was mainly transformed into $\mathrm{NO}_{2}{ }^{-}$and $\mathrm{NH}_{3}$ according to the equations (1) and (2) in the cathode chamber [6].

Fig. 3 (b) shows the effect of flow rate on $\mathrm{NO}_{3}{ }^{-}$removal rate and formation rates of $\mathrm{NO}_{2}{ }^{-}$and $\mathrm{NH}_{3}$ at the volumetric electric charge of $1,500 \mathrm{C} / \mathrm{L}$. These experiments were also conducted using the same synthetic solution in Fig. 3 (a). From Fig. 3 (b) it is observed that the $\mathrm{NO}_{3}{ }^{-}$removal rate was linearly increased with the increase in flow rate at the $\mathrm{R}^{2}$ value of 0.998. This phenomenon can be ascribed to the enhancement of the mass transfer processes.

\section{Influence of Chloride Ion Concentration on Reduction of Nitrogenous Compounds}

Fig. 4 (a), (b), (c) and (d) shows the variation of $\mathrm{TN}, \mathrm{NO}_{3}{ }^{-}$, $\mathrm{NO}_{2}^{-}, \mathrm{NH}_{3}$ and chloramines concentration after electrolysis with the presence of different dozes of $\mathrm{NaCl}$ (Table I). Here, $\mathrm{TN}$ indicates the sum of $\mathrm{NO}_{3}{ }^{-}, \mathrm{NO}_{2}{ }^{-}, \mathrm{NH}_{3}$ and chloramines nitrogen concentration. All of these experiments were performed with $1 \mathrm{mM} \mathrm{K}_{2} \mathrm{SO}_{4}, 1.42 \mathrm{mM} \mathrm{KNO}_{3}$ and varied $\mathrm{Cl}^{-}$ concentration of 100, 200, 400 and $800 \mathrm{mg} / \mathrm{L}$, respectively. In addition, Fig. 5 (e) and (f) shows the $\mathrm{NH}_{3}$ and chloramines concentration in the same effluent at $\mathrm{Cl}^{-}$concentration of 400 and $800 \mathrm{mg} / \mathrm{L}$ at the adjusted $\mathrm{pH} \mathrm{5,} 7$ and 9 respectively. The effluent $\mathrm{pH}$ was adjusted by adding the buffer solution of 100 $\mathrm{mM}$ sodium bicarbonate $\left(\mathrm{NaHCO}_{3}\right)$ with sulfuric acid $\left(\mathrm{H}_{2} \mathrm{SO}_{4}\right)$. It is well known that $\mathrm{Cl}^{-}$is converted into active $\mathrm{Cl}_{2}$ through an anodic reaction according to the equation (5) [20]. After that, the produced $\mathrm{Cl}_{2}$ rapidly hydrolyses to $\mathrm{HOCl}$ according to the equation (6) [21]. Next, the water containing $\mathrm{NH}_{3}$ or other nitrogenous substances react with $\mathrm{HOCl}$ and typically formed chloramines, namely monochloramine $\left(\mathrm{NH}_{2} \mathrm{Cl}\right)$, dichloramine $\left(\mathrm{NHCl}_{2}\right)$ and trichloramine or nitrogen trichloride $\left(\mathrm{NCl}_{3}\right)$ depending on the $\mathrm{pH}$, temperature, reaction time and other surrounding environmental conditions according to the equations (8-10). And finally, chloramines are oxidized into $\mathrm{N}_{2}$ or $\mathrm{N}_{2} \mathrm{O}$ according to the equations (15) and (16) [10].

$$
\begin{gathered}
\mathrm{NH}_{3}+\mathrm{HClO} \rightarrow \mathrm{NH}_{2} \mathrm{Cl}+\mathrm{H}_{2} \mathrm{O} \\
\mathrm{NH}_{2} \mathrm{Cl}+\mathrm{HClO} \rightarrow \mathrm{NHCl}_{2}+\mathrm{H}_{2} \mathrm{O} \\
\mathrm{NHCl}_{2}+\mathrm{HClO} \rightarrow \mathrm{NCl}_{3}+\mathrm{H}_{2} \mathrm{O} \\
2 \mathrm{NH}_{2} \mathrm{Cl} \rightarrow \mathrm{NHCl}_{2}+\mathrm{NH}_{3} \\
2 \mathrm{NH}_{2} \mathrm{Cl}+\mathrm{HOCl} \rightarrow \mathrm{N}_{2}+3 \mathrm{HCl}+\mathrm{H}_{2} \mathrm{O} \\
\mathrm{NH}_{2} \mathrm{Cl}+\mathrm{NHCl}{ }_{2} \rightarrow \mathrm{N}_{2}+3 \mathrm{HCl} \\
2 \mathrm{NHCl}_{2}+\mathrm{H}_{2} \mathrm{O} \rightarrow \mathrm{N}_{2} \mathrm{O}+4 \mathrm{HCl}
\end{gathered}
$$

The above equations can be summarized as follows:

$$
\begin{gathered}
2 \mathrm{NH}_{3}+3 \mathrm{HOCl} \rightarrow \mathrm{N}_{2}+3 \mathrm{H}_{2} \mathrm{O}+3 \mathrm{HCl} \\
2 \mathrm{NH}_{3}+4 \mathrm{HOCl}+\mathrm{H}_{2} \mathrm{O} \rightarrow \mathrm{N}_{2} \mathrm{O}+4 \mathrm{H}_{2} \mathrm{O}+4 \mathrm{HCl} \\
\mathrm{NH}_{3}+3 \mathrm{HOCl} \rightarrow \mathrm{NCl}_{3}+3 \mathrm{H}_{2} \mathrm{O}
\end{gathered}
$$

From Fig. 4 (a) and (b) it is observable that $\mathrm{NO}_{3}{ }^{-}$was transformed into $\mathrm{NO}_{2}^{-}$and $\mathrm{NH}_{3}$ in the similar trend, where $\mathrm{NH}_{3}$ and chloramines were accumulated with an increase in volumetric electric charge. However, addition of small amount of $\mathrm{Cl}^{-}(100 \mathrm{mg} / \mathrm{L}$ and $200 \mathrm{mg} / \mathrm{L})$ did not show any significance decrease in TN. Form Fig. 4 (c) it is observable that $\mathrm{NH}_{3}$ was enhanced with the increase in volumetric electric charge within the range of 300 to $2,700 \mathrm{C} / \mathrm{L}$ and it gradually decreased over $2,700 \mathrm{C} / \mathrm{L}$.

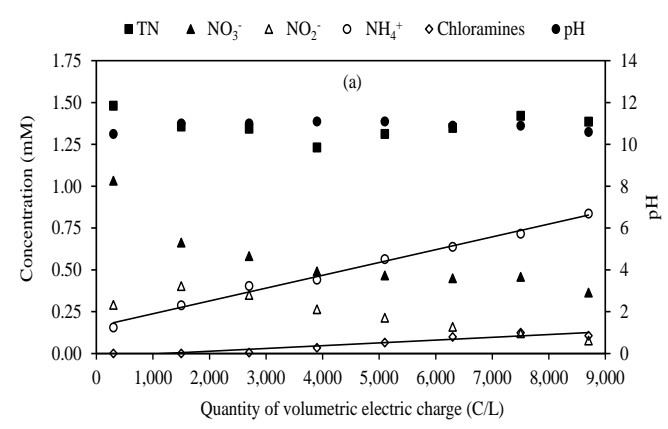



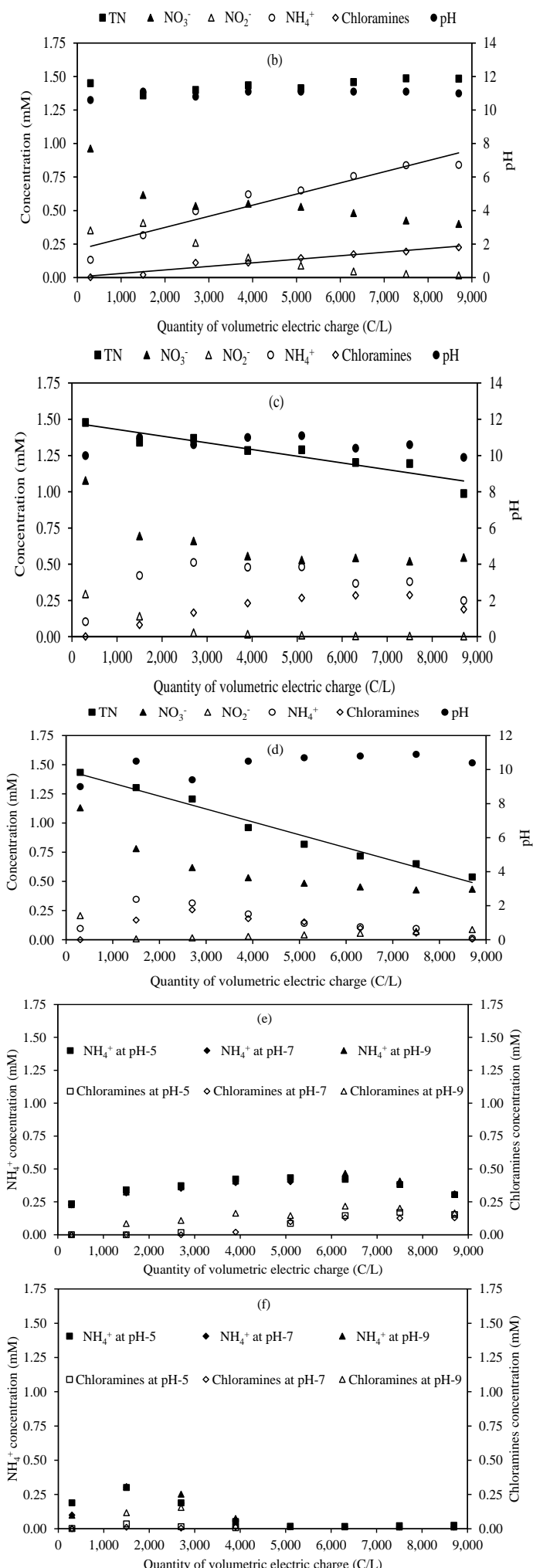

Fig. 4. Variation of $\mathrm{TN}, \mathrm{NO}_{3}{ }^{-}, \mathrm{NO}_{2}{ }^{-}, \mathrm{NH}_{3}$ and chloramines concentration in the effluent at (a) $\mathrm{Cl}$ - concentration of $100 \mathrm{mg} / \mathrm{L}$, (b) $\mathrm{Cl}$ - concentration of $200 \mathrm{mg} / \mathrm{L}$, (c) Cl- concentration of $400 \mathrm{mg} / \mathrm{L}$ and (d) Cl- concentration of $800 \mathrm{mg} / \mathrm{L}$, (e) NH3 and chloramines concentration in the same effluent at Clconcentration of $400 \mathrm{mg} / \mathrm{L}$ at $\mathrm{pH} \mathrm{5,7}$ and 9, (f) $\mathrm{NH} 3$ and chloramines concentration in the same effluent at $\mathrm{Cl}$ - concentration of $800 \mathrm{mg} / \mathrm{L}$ at $\mathrm{pH} 5$, 7 and 9 .

The chloramines concentration were increased gradually within the volumetric electric charge of 300 to $7,500 \mathrm{C} / \mathrm{L}$ but it decreased at the volumetric electric charge of $8,700 \mathrm{C} / \mathrm{L}$, where $\mathrm{TN}$ also dropped. This result indicates that chloramines were oxidized at $8,700 \mathrm{C} / \mathrm{L}$. From Fig. (e) it is found that when the effluent $\mathrm{pH}$ was adjusted at 5, 7 and 9 it showed the similar results like Fig. (c). Here, it could be considered that the reaction rate of $\mathrm{Cl}_{2}$ with $\mathrm{NH}_{3}$ over $2,700 \mathrm{C} / \mathrm{L}$ exceeded the production rate of chloramines.

Then the chloramines produced was removed by the break-point chlorination mechanism and $\mathrm{TN}$ gradually decreased [22]. From Figure 4 (d) it is also observable that $\mathrm{NH}_{3}$ accumulation rate was enhanced with the increase in volumetric electric charge within the range of 300 to 1,500 $\mathrm{C} / \mathrm{L}$ and it gradually decreased with the volumetric electric charge over 1,500 $\mathrm{C} / \mathrm{L}$. The complete consumption of $\mathrm{NH}_{3}$ was observed at the volumetric electric charge of $8,700 \mathrm{C} / \mathrm{L}$. The formation of chloramines were increased from the volumetric electric charge of 300 to $2,700 \mathrm{C} / \mathrm{L}$ and it followed the similar trend like $\mathrm{NH}_{3}$ over 2,700 C/L. Finally, TN decreased linearly with the increase in volumetric electric charge at the $\mathrm{R}^{2}$ value of 0.978 . At the volumetric electric charge of $8,700 \mathrm{C} / \mathrm{L}$ the TN was $0.54 \mathrm{mM}$ that was composed of $\mathrm{NO}_{3}{ }^{-}, \mathrm{NO}_{2}{ }^{-}, \mathrm{NH}_{4}{ }^{+}$and chloramines with the concentrations of $0.43,0.09,0.01$ and $0.01 \mathrm{mM}$, respectively.

Moreover, from Fig. (f) it is found that when the effluent $\mathrm{pH}$ was adjusted at 5, 7 and 9 the $\mathrm{NH}_{4}{ }^{+}$and chloramines were complete oxidized at the volumetric electric charge of 5,100 $\mathrm{C} / \mathrm{L}$ at $\mathrm{pH}$ 7.These results confirm that the appropriate amount of $\mathrm{Cl}^{-}$lead sufficient amount of $\mathrm{HOCl}$ production, which could oxidize the $\mathrm{NH}_{3}$ and other byproduct presumably into $\mathrm{N}_{2}$ [9]. Also, it should be noted that the $\mathrm{NH}_{3}$ formation rate increased with the increase in volumetric electric charges as shown in Figure 3 (a). On the other hand, the enhancement of $\mathrm{NH}_{3}$ removal under higher current densities is that higher current density increased the anodic potential, which is favorable to electrochemical generation of $\mathrm{Cl}_{2}$, because the standard potential of reaction [5] (1.36 V vs. SHE) is higher than that of the anodic oxidation of water (1.23 V vs. SHE). The electrode potential of anodic oxidation of $\mathrm{Cl}^{-}$can be described by the following Nernst's equation.

$$
E=E^{0}-\frac{R T}{2 F} \ln \frac{a_{C l^{-}}^{2}}{p_{C l_{2}}}
$$

where, $E$ is an electrode potential [V], $E^{0}$ is the standard potential [V], $R$ is the gas constant $\left(8.314 \mathrm{~J} \mathrm{~K}^{-1} \mathrm{~mol}^{-1}\right), T$ is an absolute temperature $[\mathrm{K}], a_{C l}$ is an activity of $\mathrm{Cl}^{-}[\mathrm{M}]$, and $p_{C l 2}$ is the partial pressure of $\mathrm{Cl}^{-}$[atm]. Since, $a_{C l^{-}}$is positively related to $\mathrm{Cl}^{-}$concentration, an increase in $\mathrm{Cl}^{-}$concentration results in a decrease in $E$, which can promote the anodic oxidation of $\mathrm{Cl}^{-}$into $\mathrm{Cl}_{2}$. Thus an increase in electric charge and $\mathrm{Cl}^{-}$concentration produced a larger amount of $\mathrm{HOCl}$, which enhanced the oxidization of $\mathrm{NH}_{3}$. The initial influent $\mathrm{pH}$ of the electrolytic solutions were within the range of 5.5 to 6.5 but in all cases the effluent $\mathrm{pH}$ after electrolysis were increased into the range of 9 to 12 . This result was thought to be due to the enhancement of equations (1) and (2) as already discussed using data in Fig. 3 (a) [2], [23], [24].

\section{Effect of Electrochemically Produced Chlorine to Occur Break-point Chlorination on Ammonia Nitrogen Removal}

Fig. 5 (a), (b), (c) and (d) shows the variation of total $\mathrm{Cl}_{2}$, free $\mathrm{Cl}_{2}$ and combined $\mathrm{Cl}_{2}$ concentration after electrolysis 
with the presence of different dozes of $\mathrm{NaCl}$ (Table I). When $\mathrm{Cl}^{-}$is added to water, it generates $\mathrm{HOCl}$. Since, $\mathrm{HOCl}$ is a weak acid, the following chemical equilibrium is established.

$$
\mathrm{HOCl} \leftrightarrow \mathrm{H}^{+}+\mathrm{OCl}^{-}
$$

In general, $\mathrm{HOCl}$ and $\mathrm{OCl}^{-}$both species altogether are known as free chlorine. These two species exist in an equilibrium condition that is $\mathrm{pH}$ dependent. This equilibrium situation is also slightly affected by the temperature. As the $\mathrm{pH}$ increases, the ratio of $\mathrm{HOCl}$ to $\mathrm{OCl}^{-}$decreases. Since the $\mathrm{pKa}$ of $\mathrm{HOCl}$ is $7.5 \mathrm{HOCl}$ is the dominant species below $\mathrm{pH}$ 7.5 and $\mathrm{OCl}^{-}$is the dominant species above $\mathrm{pH} 7.5$ [24]. The stoichiometric weight ratio of free chlorine as $\mathrm{Cl}_{2}$ to $\mathrm{NH}_{3}$ as $\mathrm{N}$ is 5.1 for $\mathrm{NH}_{2} \mathrm{Cl}$ formation (equation (8)). After $\mathrm{NH}_{2} \mathrm{Cl}$ formation, $\mathrm{NHCl}_{2}$ forms when additional $\mathrm{Cl}_{2}$ is added (equation (9)). The formation rates depend on $\mathrm{pH}$, temperature and mixing condition [25]. Similarly, $\mathrm{NCl}_{3}$ forms when additional chlorine reacts with $\mathrm{NHCl}_{2}$ (equation (10)). The sum of the combined and free chlorine in a sample is known as total chlorine. Combined chlorine includes chloramines of $\mathrm{NH}_{2} \mathrm{Cl}$ and $\mathrm{NHCl}_{2}$. From Fig. 5 (a), (b), (c) and (d) it is clearly observable that total $\mathrm{Cl}_{2}$ increased linearly with the increase in volumetric electric charge at the $\mathrm{R}^{2}$ value of $0.951,0.967,0.917$ and 0.980 , respectively. At the $\mathrm{Cl}^{-}$ concentration of 100 and $200 \mathrm{mg} / \mathrm{L}$ the free $\mathrm{Cl}_{2}$ production amount was found less than the combined $\mathrm{Cl}_{2}$. Similarly, at the $\mathrm{Cl}^{-}$concentration of $800 \mathrm{mg} / \mathrm{L}$ free $\mathrm{Cl}_{2}$ was less than the combined $\mathrm{Cl}_{2}$ from the volumetric electric charge of 300 to 2,700 C/L, but free $\mathrm{Cl}_{2}$ gradually increased and combined $\mathrm{Cl}_{2}$ gradually decreased over 2,700 $\mathrm{C} / \mathrm{L}$. In addition, Fig. (e) and (f) shows the total $\mathrm{Cl}_{2}$, free $\mathrm{Cl}_{2}$ and combined $\mathrm{Cl}_{2}$ concentration in the effluent at $\mathrm{Cl}^{-}$concentration of $400 \mathrm{mg} / \mathrm{L}$ and $800 \mathrm{mg} / \mathrm{L}$ at the adjusted $\mathrm{pH} \mathrm{5,7}$ and 9 respectively. Where free $\mathrm{Cl}_{2}$ was found at $\mathrm{pH}$ 9. Fig. 6 (a) shows the production of free $\mathrm{Cl}_{2}$ at different dozes of $\mathrm{NaCl}$ without $\mathrm{KNO}_{3}$ addition. From Fig. 6 (a) it is clearly observed that the free $\mathrm{Cl}_{2}$ production rate at the $\mathrm{Cl}^{-}$concentration of 100, 200, 400 and $800 \mathrm{mg} / \mathrm{L}$ was linearly increased with respect to the volumetric electric charge at the $\mathrm{R}^{2}$ value of $0.989,0.958$, 0.988 and 0.981 , respectively. This results mean that the current efficiency for $\mathrm{Cl}_{2}$ production did not depend on the volumetric electric charge. On the contrary, the current efficiency increased with the rise in $\mathrm{Cl}^{-}$from $0.4 \%$ for 100 $\mathrm{mg}-\mathrm{Cl}^{-} / \mathrm{L}$ to $6.1 \%$ for $800 \mathrm{mg}-\mathrm{Cl}^{-} / \mathrm{L}$. Thus, $\mathrm{Cl}^{-}$concentration had a strong influence on $\mathrm{Cl}_{2}$ production at the anode. When $\mathrm{Cl}_{2}$ consumption for $\mathrm{TN}$ removal is estimated by subtraction of the residual free $\mathrm{Cl}_{2}$ and 1.5 times of chloramines in Fig. 5 from the produced free $\mathrm{Cl}_{2}$ in Fig. 6 (a), the relationship between $\mathrm{TN}$ removal and $\mathrm{Cl}_{2}$ consumption in the case of $\mathrm{Cl}^{-}$ concentration of 400 and $800 \mathrm{mg} / \mathrm{L}$ is plotted in Fig. 6 (b).

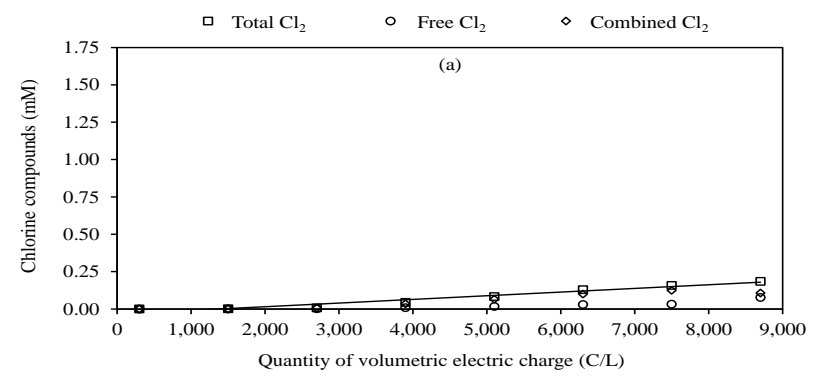

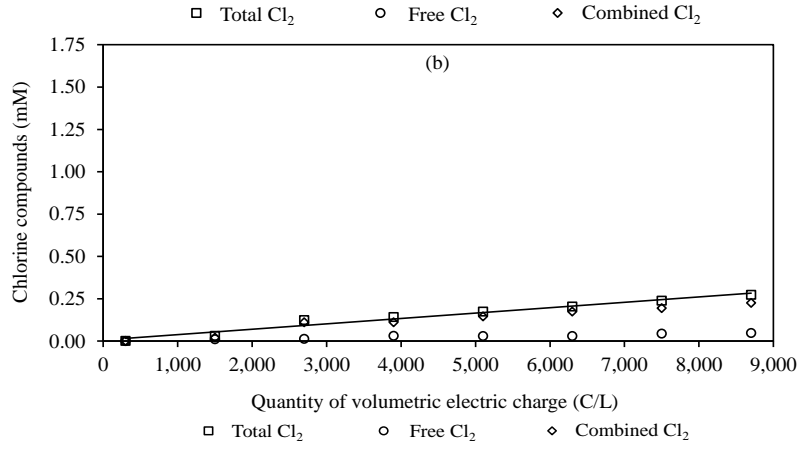
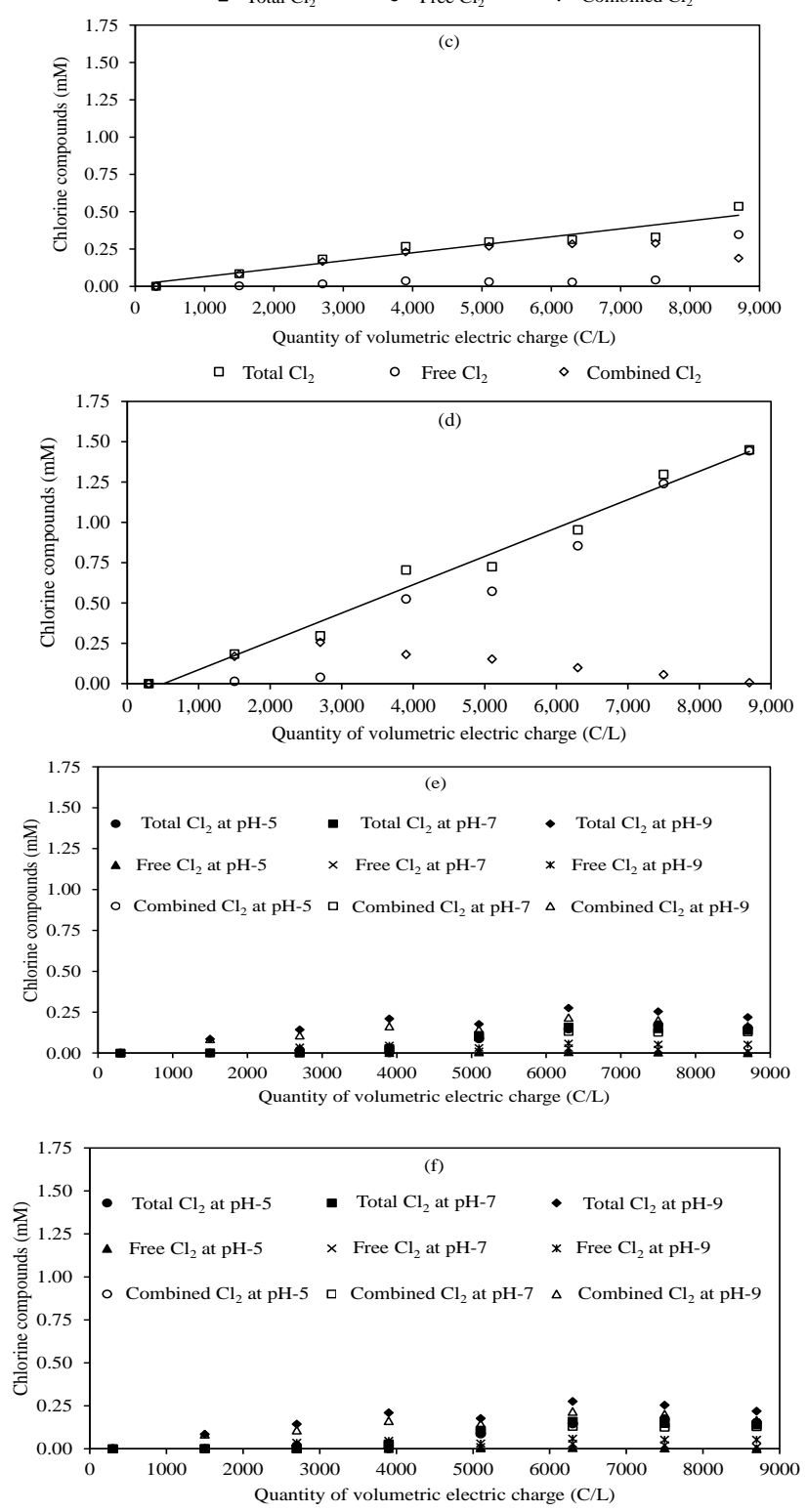

Fig. 5. Variation of total $\mathrm{Cl}_{2}$, free $\mathrm{Cl}_{2}$ and combined $\mathrm{Cl}_{2}$ concentration in the effluent at (a) Cl- concentration of $100 \mathrm{mg} / \mathrm{L}$, (b) Cl- concentration of 200 $\mathrm{mg} / \mathrm{L}$, (c) Cl- concentration of $400 \mathrm{mg} / \mathrm{L}$ and (d) Cl- concentration of 800 $\mathrm{mg} / \mathrm{L}$, (e) total $\mathrm{Cl}_{2}$, free $\mathrm{Cl}_{2}$ and combined $\mathrm{Cl}_{2}$ concentration in the effluent at $\mathrm{Cl}$ - concentration of $400 \mathrm{mg} / \mathrm{L}$ at pH 5, 7 and 9, (f) total $\mathrm{Cl}_{2}$, free $\mathrm{Cl}_{2}$ and combined $\mathrm{Cl}_{2}$ concentration in the effluent at $\mathrm{Cl}$ - concentration of $800 \mathrm{mg} / \mathrm{L}$ at $\mathrm{pH} 5,7$ and 9 .

The slope of the regression line was $0.783 \mathrm{mM}-\mathrm{N} / \mathrm{mM}^{-\mathrm{Cl}_{2}}$, which is equivalent to the molar ratio of $\mathrm{Cl}_{2}$ consumption to $\mathrm{TN}$ removal of 1.28. Based on the equations (15) and (16), the theoretical molar ratio of chlorine to $\mathrm{NH}_{3}$ is projected to be 1.5 for $\mathrm{N}_{2}$ evolution and 2 for $\mathrm{N}_{2} \mathrm{O}$ evolution. Although the observed molar ratio was slightly smaller than the theoretical molar ratio due to the uncertainty of estimation of $\mathrm{Cl}_{2}$ 
consumption for chloramine accumulation, it was close to the theoretical molar ratio for $\mathrm{N}_{2}$ evolution. Therefore, the main $\mathrm{TN}$ removal pathway in this study was inferred to be the $\mathrm{N}_{2}$ evolution as shown in equation [15].
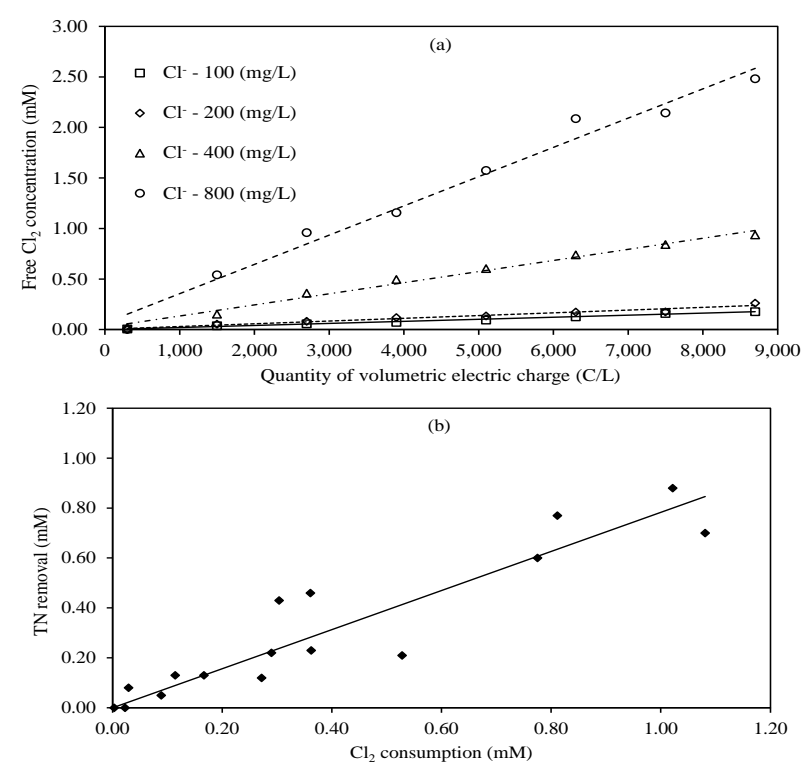

Fig. 6. (a) Production of free $\mathrm{Cl}_{2}$ without addition of $\mathrm{NO}_{3}$ - at different $\mathrm{Cl}$ concentration. The test solution contained $1 \mathrm{mM}$ of $\mathrm{K}_{2} \mathrm{SO}_{4}$ as a supporting electrolyte and (b) relationship between $\mathrm{TN}$ removal and $\mathrm{Cl}_{2}$ consumption at $\mathrm{Cl}$ - concentration of 400 and $800 \mathrm{mg} / \mathrm{L}$. The $\mathrm{Cl}_{2}$ consumption was corrected by the residual free $\mathrm{Cl}_{2}$ and residual chloramines.

\section{CONCLUSION}

In order to develop the method of electrochemical removal of $\mathrm{NO}_{3}{ }^{-}$, a two-compartment electrochemical flow cell with copper mesh cathode and Ti/Pt anode was developed and its performances was evaluated using synthetic water containing $1.42 \mathrm{mM}$ of $\mathrm{NO}_{3}{ }^{-}$. The effects of volumetric electric charge, flow rate and $\mathrm{Cl}^{-}$concentrations were demonstrated in this study, in which the volumetric electric charge was regulated by the change in electrolytic current. The volumetric electric charge enhanced both $\mathrm{NO}_{3}{ }^{-}$reduction to $\mathrm{NH}_{3}$ and anodic production of $\mathrm{Cl}_{2}$, but it did not change the current efficiency. The flow rate also enhanced the electrochemical reactions due to the promotion of mass transfer process. The $\mathrm{Cl}^{-}$ concentration improved the current efficiency of $\mathrm{Cl}_{2}$ production. As a result, TN removal was accelerated via the break-point chlorination mechanism, in which the $\mathrm{N}_{2}$ evolution pathway was thought to be main pathway of $\mathrm{TN}$ removal in this study. However, the current efficiency remained a low level; only $6.1 \%$ at $\mathrm{Cl}^{-}$concentration of 800 $\mathrm{mg} / \mathrm{L}$. In spite of the low current efficiency, $1.42 \mathrm{mM}$ of initial $\mathrm{NO}_{3}{ }^{-}$was decreased to $0.43 \mathrm{mM}$ without $\mathrm{NH}_{3}$ and $\mathrm{NO}_{2}{ }^{-}$ accumulation during 1.0 minute contact time for $\mathrm{NO}_{3}^{-}$ reduction and 15 seconds contact time for $\mathrm{Cl}_{2}$ production at the volumetric electric charge of $5,100 \mathrm{C} / \mathrm{L}$, flow rate of 20 $\mathrm{mL} / \mathrm{min}, \mathrm{Cl}^{-}$concentration $800 \mathrm{mg} / \mathrm{L}$ at $\mathrm{pH}$ 7. As a consequence, this research provide a feasible foundation for the rapid removal of nitrate from water streams. However, further studies will be required for a practical application of this technique such as developing highly catalytic electrode materials and exploring the efficiency of $\mathrm{pH}$ control on the electrochemical denitrification.

\section{REFERENCES}

[1] G. Chen, "Electrochemical technologies in wastewater treatment," Journal of Separation and Purification Technology, vol. 38, issue 1, pp. 11-41, 2004.

[2] S. H. Lin and C. L. Wu, "Electrochemical removal of nitrite and ammonia for aquaculture," Journal of Water Research, vol. 30, no. 3, pp. 715-721, 1996.

[3] S. A. R. Mousavi, S. Ibrahim, M. K. Aroua, and S. Ghafari, "Bio-electrochemical denitrification," A review: International Journal of Chemical and Environmental Engineering, vol. 2, no. 2, pp. 140-146, 2011.

[4] H. A. Duarte, K. Jha, and J. W. Weidner, "Electrochemical reductions of nitrates and nitrites in alkaline media in the presence of hexavalent chromium," Journal of Applied Electrochemistry, vol. 28, pp. 811-817, 1998.

[5] S. Ureta-Zanartu and C. Yanez, "Electroreduction on nitrate ion on Pt, Ir and on 70:30 Pt:Ir alloy," Journal of Electrochimica Acta, vol. 42, issue 11, pp. 1725-1731, 1997.

[6] B. P. Dash and S. Chaudhari, "Electrochemical denitrification of simulated groundwater," Journal of Water Research, vol. 39, issue 17, pp. 4065-4072, 2005.

[7] K. Bouzek, M. Paidar, A. Sadilkova, and H. Bergmann, "Electrochemical reduction of nitrate in weakly alkaline solutions," Journal of Applied Electrochemistry, vol. 31, issue 11, pp. 1185-1193, 2001.

[8] M. Li, C. Feng, Z. Zhang, Z. Shen, and N. Sugiura, "Electrochemical reduction of nitrate using various anodes and a $\mathrm{Cu} / \mathrm{Zn}$ cathode," Journal of Electrochemistry Communications, vol. 11, pp. 1853-1856, 2009.

[9] M. Li, C. Feng, Z. Zhang, and N. Sugiura, "Efficient electrochemical reduction of nitrate to nitrogen using Ti/IrO2-Pt anode and different cathodes," Journal of Electrochimica Acta, vol. 54, issue. 20, pp. 4600-4606, 2009.

[10] T. A. Pressley, D. F. Bishop, and S. G. Roan, "Ammonia-nitrogen removal by breakpoint chlorination," Journal of Environmental Science and Technology, vol. 6, issue 7, pp. 622-628, 1972.

[11] C. P. Feng, N. Sugiura, S. Shimada, and T. Maekawa, "Development of a high performance electrochemical wastewater treatment system," Journal of Hazardous Materials, vol. 103, issues 1-2, pp. 65-78, 2003.

[12] C. Polatides, M. Dortsiou, and G. Kyriacou, "Electrochemical removal of nitrate ion from aqueous solution by pulsing potential electrolysis," Journal of Electrochimica Acta, vol. 50, pp. 5237-5241, 2005.

[13] J. F. E. Gootzen, P. G. J. M. Peeters, J. M. B. Dukers, L. Lefferts, W. Visscher, and J. A. R. V. Veen, "The electrolytic reduction of $\mathrm{NO}_{3}{ }^{-}$on $\mathrm{Pt}$, Pd and Pt+Pd electrodes activated with Ge," Journal of Electroanalytical Chemistry, vol. 434, issues 1-2, pp. 171-183, 1997.

[14] I. Katsounaros and G. Kyriacou, "Influence of the concentration and the nature of the supporting electrolyte on the electrochemical reduction of nitrate on tin cathode," Journal of Electrochimica Acta, vol. 52, pp. 6412-6420, 2007.

[15] Standard Methods for the Examination of Water and Wastewater, APHA, American Public Health Association, Washington, DC, USA, 1999.

[16] D. De, E. E. Kalu, P. P. Tarjan, and J. D. Englehardt, "Kinetic studies of the electrochemical treatment of nitrate and nitrite ions on iridium-modified carbon fiber electrodes," Journal of Chemical Engineering and Technology, vol. 27, issue 1, pp. 56-64, 2004.

[17] N. V. Thinh, N. T. P. Thoa, and L. Q. Hung, "Cyclic voltammetry study on the reduction of nitrate and nitrite on a copper electrode," Journal of Chemistry, vol. 45, issue. 2, pp. 213-218, 2007.

[18] M. Li, C. Feng, Z. Zhang, S. Yang, and N. Sugiura, "Treatment of nitrate contaminated water using an electrochemical method," Journal of Bioresource Technology, vol. 101, pp. 6553-6557, 2010.

[19] P. K. R. Prashad, M. N. Priya, and K. Palanivelu, "Nitrate removal from groundwater using electrolyte reduction method," Indian Journal of Chemical Technology, vol. 12, pp. 164-169, 2005.

[20] D. De, J. D. Englehardt, and E. E. Kalu, "Cyclic voltammetric studies on nitrate and nitrite ion reduction at the surface of iridium-modified carbon fiber electrode," Journal of Electrochemical Society, vol. 147 , issue 11, pp. 4224-4228, 2000

[21] K. Rajeswar and J. G. Ibanez, "Environmental electrochemistry fundamentals and applications in pollution abatement," Academic Press, San Diego, 1997. 
[22] D. Pletcher and Z. Poorabedi, "The reduction of nitrate at a copper cathode in aqueous acid," Journal of Electrochimica Acta, vol. 24, issue 12, pp. 1253-1256, 1979.

[23] L. C. Chiang, J. E. Chang, and T. C. Wen, "Indirect oxidation effect in electrochemical oxidation treatment of landfill leachate," Journal of Water Research, vol. 29, no. 2, pp. 671-678, 1995.

[24] L. Li and Y. Liu, "Ammonia removal in the electrochemical oxidation: Mechanism and pseudo-kinetics," Journal of Hazardous Materials, vol. 161, issues 2-3, pp. 1010-1016, 2009.

[25] R. M. Chapin, "Dichloro-amine," Journal of the American Chemical Society, vol. 51, issue 7, pp. 2112-2117, 1929.

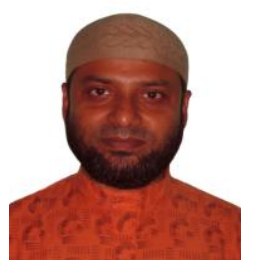

A. K. M. Ashadullah is now a $\mathrm{PhD}$ student in the Department of Environmental Solution Technology, Graduate School of Science and Technology, Ryukoku University, Japan. He obtained his master of engineering on environmental and urban engineering from Ritsumeikan University, Japan and the bachelor of engineering on agricultural engineering major in farm structure and environmental engineering from Bangladesh Agricultural University, Bangladesh. 